CUAJ honors its members and friends who have passed away. We invite colleagues of the deceased to submit brief remembrances. Please limit your notice to 200 words. Send your notice to journal@cua.org or fax it to 514-395-1664.
Cite as: Can Urol Assoc J 2019;13(8):288. http://dx.doi.org/10.5489/cuaj.6162

Contributed by Dr. Anil Kapoor, Department of Urology, McMaster University, Hamilton, ON

\section{Dr. John Paul Joseph Whelan}

With great sadness we announce the passing of Dr. Paul Whelan on June 29, 2019 at the Royal Jubilee Hospital in Victoria, BC. Paul fought a courageous battle with cancer and passed at the young age of 62 . He had a prolific career as an academic urologist

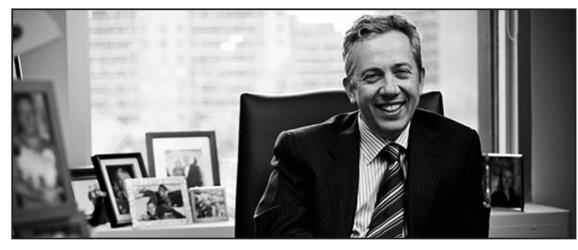
for over 30 years and left a significant impact on the Canadian urologic community.

Paul graduated from McMaster University with his MD in 1981 and completed his urology residency at Western University. He started practice in Hamilton in 1988 after completing his fellowships in endourology and stone disease at the University of Florida and University of Pennsylvania. He stayed with McMaster University until 2013, and then joined the Vancouver Island Health Authority as Executive Medical Director.

During his time at McMaster University, he founded the McMaster Institute of Urology and was the inaugural holder of the Braley-Gordon Chair in Urology. He was instrumental in starting the McMaster Urology residency training program in 1999, which would be accredited by the Royal College of Physicians and Surgeons in 2001, and was Program Director for the first five years of the training program. He was the Academic Head of the Division of Urology from 2003-2013 and recruited the majority of the current faculty in the Division of Urology. Paul immensely enjoyed his time teaching, training, and graduating urology residents, and received a number of teaching awards as a committed educator. The residents he graduated all deeply feel his untimely passing.

As Executive Medical Director of Vancouver Island Health from 2013 onwards, Paul was credited with transforming the surgical program during his tenure there. As an active member of the Canadian Urological Association, Paul was a member since 1988, and actively involved in the Post-graduate Training Committee from 2002-2007 and the CUASF Administrative Council from 2011-2014.

Paul was an avid golfer and dedicated to the game. He was always patient golfing with his less skilled partners. He was an avid cyclist, traveler, and cook. Paul lived life to the fullest and had a great sense of humor. We will fondly remember his lively stories that always engaged his colleagues, and will continue to be retold in his memory.

The Canadian Urological Association and its members offer sincerest condolences to Paul's family and friends over his untimely passing. He will be sorely missed by all of us. 